\title{
Ethnobotanical Study on Tidung Tribe in Using Plants for Medicine, Spice, and Ceremony
}

\author{
Listiani $^{1}$, Fadhlan Muchlas Abrori ${ }^{1}$
}

\begin{abstract}
Ethnobotany is a study that is related to plants and their use. This study is based on the reality that human kinds cannot be separated from their nature. Interestingly, different tribes has different ways in using natural resources. In in Indonesia, study ethnobotany has enriched the variety of ethnobiology study. This is because Indonesia has various tribes and each tribe has their own ways in interacting with their nature, including the way they use plants for daily life. One of tribes that has been studied is Tidung. Tidung is a tribe that inhabits the north area of Kalimantan, Indonesia. This tribe is using plants for medicine, spice, and ceremony. This study has been done by interviewing people who are Tidung tribe. The result shows that there are $\mathbf{2 0}$ medicinal plant species, 16 spice plant species, and eight ceremonial plant species. Mostly, the Tidung tribe use plants for medicine which means that this tribe highly depends on the nature of mainataining their health.
\end{abstract}

Keywords—ethnobotany, tidung, medicinal, spice, ceremonial plants.

\section{INTRODUCTION}

$\mathrm{R}$ esearch on ethnobotany has been done for more than a hundred year. Indonesia is one of countries that has high variety on culture and tribes. These culture and tribes are important factors in ethnobiology study. In fact, research in ethnobiology is really rarely held in Indonesia and if there is ethobiology study, this study is more related to a study on ethnobotany in the society. Ethnobotany is part of ethnobiology, in which ethnobotany studies plants and their usage for mankind [1]. Unfortunately, study on ethnobotany is less been done in Indonesia even though Indonesia has big potential as a place for ethnobotanical study.

Furthermore, Indonesia is a country that has high variety on natural resources consisted of plants and animals. On the other hand, Indonesia is well known as a country that has various local tribes. Indeed, most of Indonesian indigenous people highly depend on the nature in fulfilling their daily need. This can be shown from the number of local people who use plants and animals in their life such as using plants for food, medicine, and ceremony [1].

One of Indonesian tribes that is well known in using natural resources is Tidung. Tidung is one of tribes that inhabits in the area of Kalimantan, especially the north part of Kalimantan. Tidung tribe has knowledge in using plants for medicine, spice, and ceremony. On the other hand, this tribe also has their own way in classifying the plant usage, especially plants for medicine, spice, and ceremony. Also, Tidung has several reasons in classifying plants. Medicinal, spice, and ceremonial plants that has been used by Tidung has many variations and unique. Because of its variation, then Tidung classified them. In Biology, classifying of living things is known as taxonomy.

Actually, classification system has been well known since long time ago. A conventional classification system is classification using local language that is based local

${ }^{1}$ Listiani and Fadhlan Muchlas Abrori are with Departement of Departement of Biological Education, Borneo University Tarakan, Tarakan, 77123, Indonesia. E-mail: listiani.asrin84@gmail.com; fadhlan1991@gmail.com. knowledge. This way of classification is called as FolkTaxonomy. The Folk-Taxonomy has been used far before modern taxonomy that is used today [2].

Instead of the way of local people in classifying plants, the more important thing is about how they use those plants for their daily life. Research on this topic called as ethnobotanical study. It cannot be denied that many Indonesian people are still hold on their tradition in their life. For example, some people still use traditional medicine from plants or animal instead of taking synthetic medicine. In addition, World Health Organization (WHO) highly recommended the usage of traditional medicine for maintaining health, preventing diseases, especially degenerative diseases and cancer [3]. This is because the use of traditional medicine is safer than modern medicine if it is used correctly. Sari [3] found that the traditional medicine is safe to use if people know how to select the right plant and have knowledge on the use of chemical substances inside the plants. For example, a species from Zingiberaceae, Zingiber zerumbet has been used as a medicine for improving appetite. Instead of the chemical substances inside the plants, people should consider the dosage. Similar with modern medicine, dosage is important in the usage of traditional medicine.

Another interesting thing that can be studied from ethnobotany is the usage of plants for spices. As we know that Indonesian people highly depend on plants for spices. Indeed, people love having strong spice in preparing their food. As medicinal plants, there are also several kinds of spice plants. Generally, there are two kinds of spice plants. First, dry spice plants, which are preserved by dried. Second, wet spice plants that is stored in wet condition and not long last.

Lastly, some tribes in Indonesia still held traditional ceremonies. They have various traditional ceremonies and using plants for those ceremonies. Some tribes that still held traditional ceremonies are Dayak, Melayu [4], Tidung, and many others.

Therefore, study on ethnobotany is important for maintaining local knowledge and local biodiversity. In Kalimantan, there are many local tribes, such as Dayak, Tidung, and Melayu. Each tribe has their way in interacting with nature. 


\section{METHODOLOGY}

This research is qualitative research. Qualitative research is a research that is related to idea, perception, opinion, and beliefs of the research object. In qualitative research, everything cannot be measured using numbers. In addition, the theory that is used is not forced to obtain whole information from the perception of people opinion as one of the research object [5].

The research object in this research is plant species that has been used by Tidung in their daily life, which is consisted of medicinal, spice, and traditional ceremony plants. Then, the subject on this research is some people who are the representation of Tidung who have knowledge in identifying medicinal, spice, and ceremonial plants. Theose people should represent three kinds of Tidung, which are Tidung Sesayap, Tidung Sembakung-Sebuku, and Tidung Bulungan. There are nine people that has been selected as the representation of each Tidung tribe. Each Tidung group has three representative people.

Furthermore, the data in this research is qualitative data that has been obtained from primary and secondary sources. Primary source is data source that provide information directly to the data collector [6]. This primary source data can be notes resulted from interview between the researchers and the research subjects.

On the other hand, the secondary data sources are data source that do not provide information directly to the data collector. The secondary data sources can be a further process of primary data, which presented in a different formation or the data that has been obtained from other people [6]. This data can be used to support information from primary data (interview). In this research, the researchers using secondary data from literature study. The literature study is important for helping the researchers in obtaining data to support the research.

Another important thing that should be considered is the technique in collecting data. In this research, the data has been collected using two techniques, which are interview and documentation. Interview is a conversation between two people, who are the interviewer (giving questions) and the interviewee (answering questions) [7]. The interviewer in this research is the researcher and the interviewees are the representation people of Tidung tribe.

In term of documentation, the documentation process is a method in collecting data. In this case, the data can be obtained from books, Internet, or other documents that can support the research. Document is a note about fact that has been done. The researchers collect documents such as articles, pictures, or monumental work of a person [6]. In this research, the researchers use pictures of plant species that has been used by Tidung tribe as medicinal, spice, and ceremonial plants. The researchers also use some identification books, which are Flora written by Stenis V.J, Botany Illustrated written by Glimn-Lacy and Kaufman, and other related journal articles.

After the data has been collected, then the data is analyzed. The data is analyzed using qualitative descriptive method, which means that the data from the research are described thoroughly [6]. First step that should be done in analyzing data for this research is plant species identification. The identification process has been done by taking notes of morphological characteristics that consist of the characteristic of flower, leaf, stem, fruit, and other parts. The next step is making description on those notes and comparing the notes with plant identification books. After identifying the plant species, then the researchers reduce the information that has been gathered. Reducing means that the researchers is summing up information, selecting the most important thing then finding the theme and pattern [6]. In this stage, the researchers select information that is relevant and information that is not relevant to the research topic. When the data and information has been reduced, the data can be more specific and focus on the research problem that should be solved. This means that the data has provided a clear picture of research object. In this research, the data related classification system of Tidung tribe on plant species that they use for their daily life has been reduced to be more concise.

Lastly, the data that has been analyzed then be presented. The data is presented as tables, graphs, and charts. Instead of tables, graphs, and charts, the data are also described. The descriptions are based on plant identification and data reduction.

\section{RESULT AND DISCUSSION}

The result on ethnobotanical study has been done in North Kalimantan, Indonesia. The subject of this research is group of Tidung tribe who are inhabit in Tarakan, Bulungan, and Sembakung. The researchers has interviewed nine people who are the representation of three group of Tidung, which are Tidung-Bulungan, Tidung Sembakung-Sebuku, and Tidung Sesayap. The data show that there are 39 species has been found and used by Tidung tribe in their daily life. From those 39 species, there are some species used for medicine, spices, and traditional ceremonies. The name of those species and the usage are presented on Table 1. In addition, the name of species with their family is presented on Table 2.

Table 1 shows that there are 38 plant species that Tidung tribe use in their daily life. From those 38 plant species, there are 20 species used as medicine. Three of 20 species is also used as spices. In addition, the majority, there are twelve plant species that is mainly used as spices. So, there are fifteen plant species that is useful for spices. Interestingly, from those fifteen spice plants, two species are used in traditional ceremony. Instead of those two species, there are also six plant species that are used in traditional ceremony.

Furthermore, Table 2 shows information on the name of the plant family and their species that are used by Tidung tribe. From the table, it is known that there are 22 plant families used by Tidung tribe. From those 22 Families, plant species from three families, Zingiberaceae, Poaceae, and Piperaceae are more used by the Tidung tribe. Mostly, only one plant species from other families that can be used by Tidung in their life.

Another interesting thing that can be notified from this research is the domination of family Zingiberaceae in Tidung tribe activities. Figure 1 shows that there are six species from Zingiberaceae that are used by Tidung, 
either as medicine or spices. The next family that has the number of species used the most is Piperaceae, then 


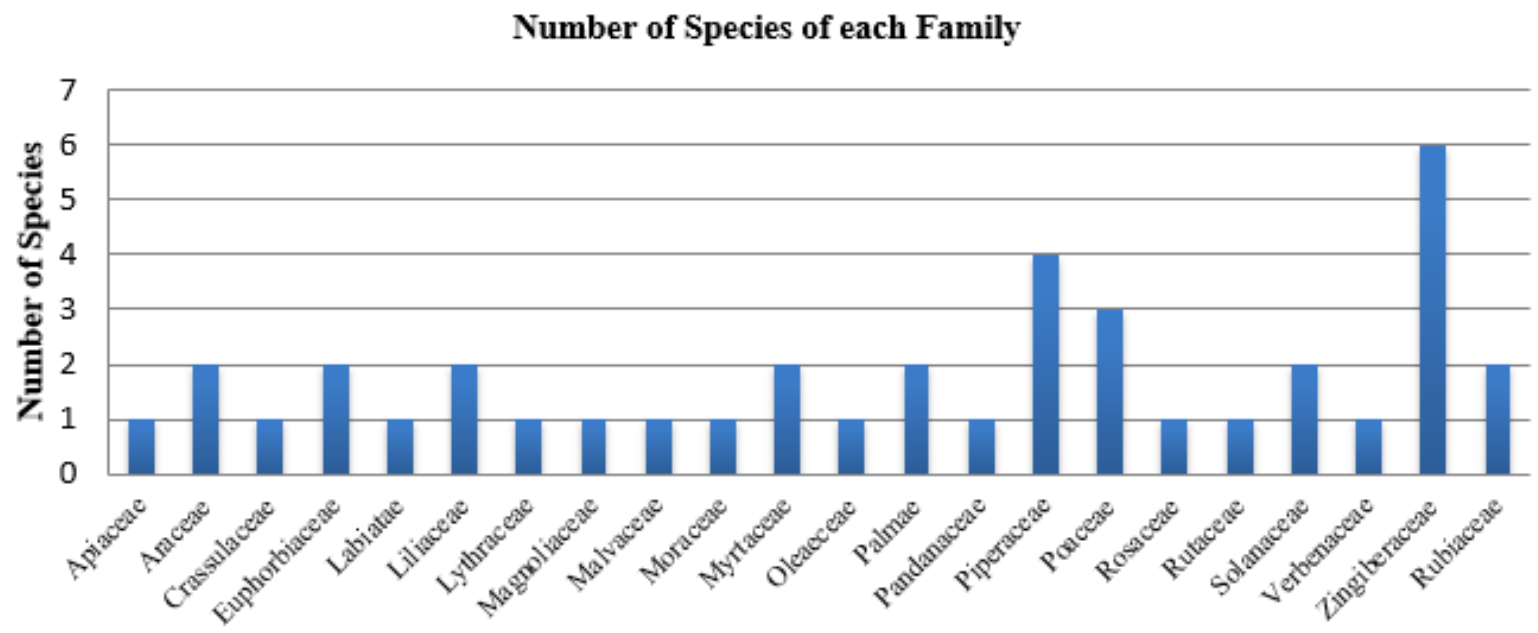

\section{Plant Family}

Figure 1. The number of species each family that has been used as medicine, spice, and traditional ceremony of Tidung.

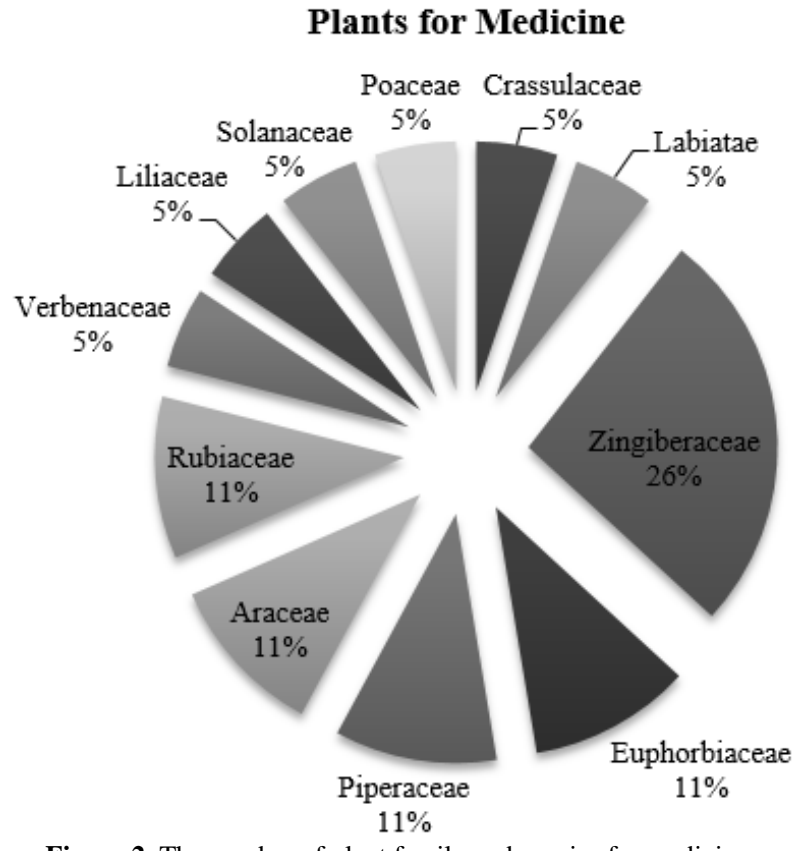

Figure 2. The number of plant family and species for medicine.

\section{Plants for Spices}

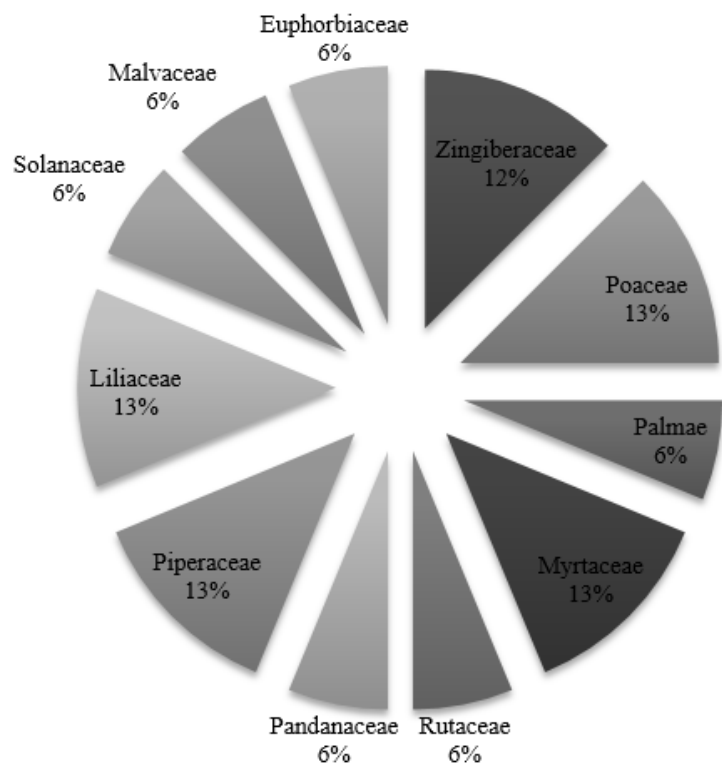

Figure 3. The number of plant family and species for spices.

\section{Plants for Traditional Ceremony}

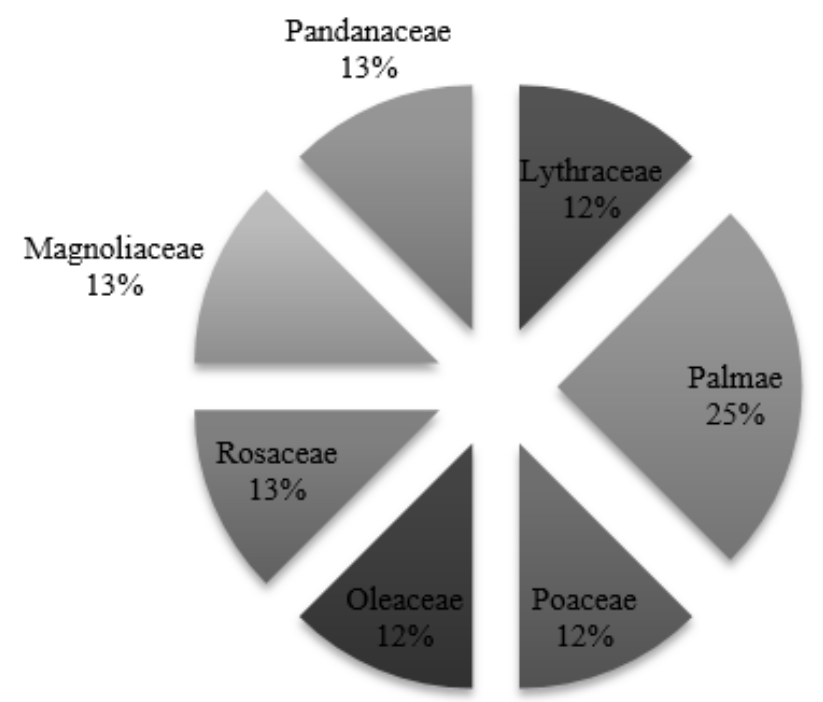

Figure 4. The number of plant family and species for traditional ceremony. 


\section{Combination in Plant Family Usage}

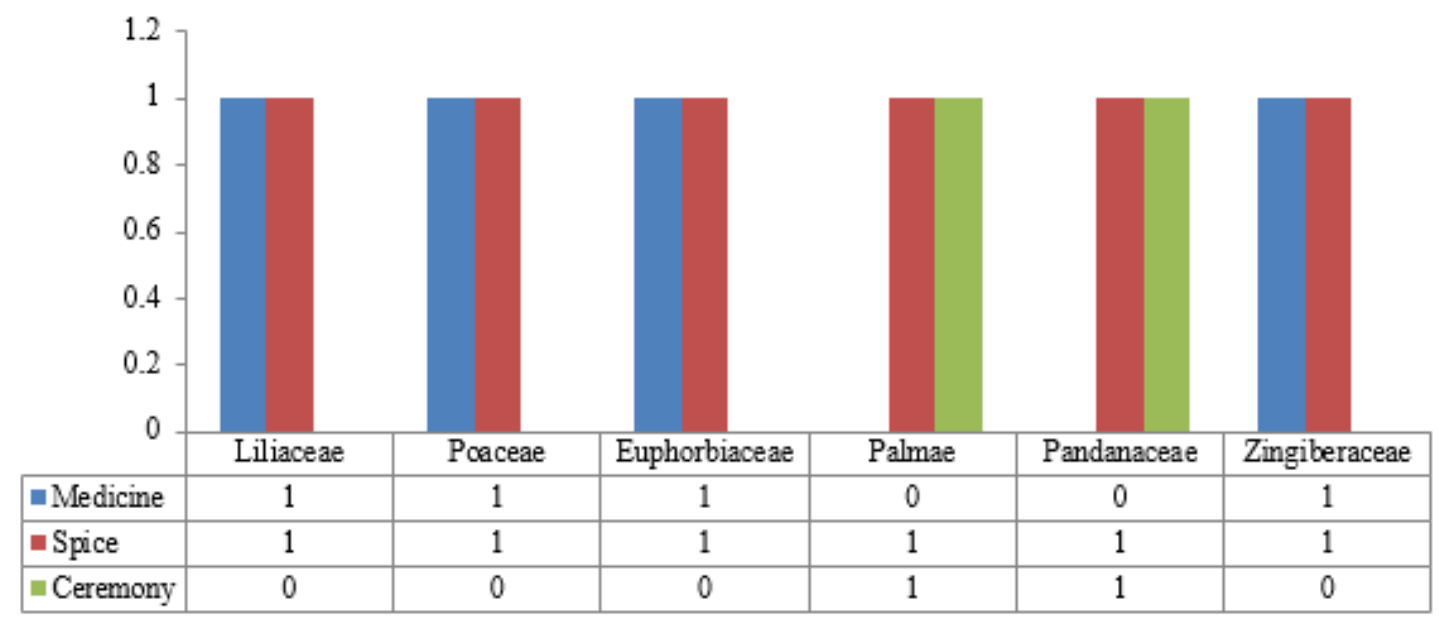

Medicine

- Spice

nCeremony

\section{Plant Family}

Figure 5. The number of plant families that have more than one usage.

TABEL 1.

PLANT SPECIES FOR MEDICINE, SPICES, AND TRADITIONAL CEREMONY OF TIDUNG

\begin{tabular}{|c|c|c|c|c|c|}
\hline \multirow[t]{2}{*}{ No. } & \multirow[t]{2}{*}{ Plant species } & \multirow[t]{2}{*}{ Family } & \multicolumn{3}{|c|}{ Plant Usage } \\
\hline & & & Medicine & Spice & Ceremony \\
\hline 1 & Kalanchoe pinnata (Lam.) Pers. & Crassulaceae & $\sqrt{ }$ & & \\
\hline 2 & $\begin{array}{l}\text { Orthosiphon aristatus } \\
\text { (Blume) Miq.) }\end{array}$ & Labiatae & $\sqrt{ }$ & & \\
\hline 3 & Kaempferia galanga $\mathrm{L}$. & Zingiberacea & $\sqrt{ }$ & & \\
\hline 4 & Curcuma longa $\mathrm{L}$. & Zingiberaceae & $\sqrt{ }$ & & \\
\hline 5 & Ricinus communis L. & Euphorbiacea & $\sqrt{ }$ & & \\
\hline 6 & Piper betle L. & Piperacea & $\sqrt{ }$ & & \\
\hline 7 & Colocasia esculenta (L.) Schott & Araceae & $\sqrt{ }$ & & \\
\hline 8 & Artocarpus altilis (Parkinson) Fosberg & Moraceae & $\sqrt{ }$ & & \\
\hline 9 & Coffea sp. & Rubiacea & $\sqrt{ }$ & & \\
\hline 10 & Clerodendron calamitosum L. & Verbenaceae & $\sqrt{ }$ & & \\
\hline 11 & Zingiber officinale Roscoe. & Zingiberacea & $\sqrt{ }$ & $\sqrt{ }$ & \\
\hline 12 & Acorus calamus L. & Araceae & $\sqrt{ }$ & & \\
\hline 13 & Curcuma xanthorrhiza Roxb. & Zingiberacea & $\sqrt{ }$ & & \\
\hline 14 & Kaempferia rotunda L. & Zingiberacea & $\sqrt{ }$ & & \\
\hline 15 & Allium sativum L. & Liliacea & $\sqrt{ }$ & $\sqrt{ }$ & \\
\hline 16 & Capsicum annuum L. & Solanaceae & $\sqrt{ }$ & & \\
\hline 17 & Imperata cylindrical (L.) Raeusch. & Poaceae & $\sqrt{ }$ & $\sqrt{ }$ & \\
\hline 18 & Morinda citrifolia L. & Rubiacea & $\sqrt{ }$ & & \\
\hline 19 & Manihot esculenta Crantz. & Euphorbiaceae & $\sqrt{ }$ & $\sqrt{ }$ & \\
\hline 20 & Piper ornatum N.E.Br. & Piperaceae & $\sqrt{ }$ & & \\
\hline 21 & Alpinia galanga (L.) Willd. & Zingiberaceae & & $\sqrt{ }$ & \\
\hline 22 & Cymbopogon citratus (DC.) Stapf. & Poaceae & & $\sqrt{ }$ & \\
\hline 23 & Cocos nucifera L. & Palmae & & $\sqrt{ }$ & $\sqrt{ }$ \\
\hline 24 & Syzygium polyanthum (Wight) Walpers. & Myrtaceae & & $\sqrt{ }$ & \\
\hline 25 & Citrus sp. & Rutaceae & & $\sqrt{ }$ & \\
\hline 26 & Pandanus amaryllifolius Roxb. & Pandanaceae & & $\sqrt{ }$ & $\sqrt{ }$ \\
\hline 27 & Piper nigrum L. & Piperaceae & & $\sqrt{ }$ & \\
\hline 28 & Coriandrum sativum L. & Piperaceae & & $\sqrt{ }$ & \\
\hline 29 & Rhodomyrtus tomentosa (Aiton) Hassk. & Myrtaceae & & $\sqrt{ }$ & \\
\hline 30 & Allium cepa L. & Liliaceae & & $\sqrt{ }$ & \\
\hline 31 & Solanum lycopersicum L. & Solanaceae & & $\sqrt{ }$ & \\
\hline 32 & Durio kutejensis Hassk. \& Becc. & Malvaceae & & $\sqrt{ }$ & \\
\hline 33 & Lawsonia inermis L. & Lythraceae & & & $\sqrt{ }$ \\
\hline 34 & Areca catechu L. & Palmae & & & $\sqrt{ }$ \\
\hline 35 & Oryza sativa L. & Poaceae & & & $\sqrt{ }$ \\
\hline 36 & Jasminum sambac (L.) Sol. ex Aiton & Oleaceae & & & $\sqrt{ }$ \\
\hline 37 & Rosa sp. & Rosaceae & & & $\sqrt{ }$ \\
\hline 38 & Magnolia champaca & Magnoliaceae & & & $\sqrt{ }$ \\
\hline
\end{tabular}


TABEL 2.

PLANT PAMILY AND SPECIES THAT IS USED BY TIDUNG

\begin{tabular}{|c|c|c|}
\hline No & Family & Plant Species \\
\hline 1 & Apiaceae & Coriandrum sativum L. \\
\hline \multirow[t]{2}{*}{2} & Aráceae & Colocasia esculenta (L.) Schott \\
\hline & & Acorus calamus L. \\
\hline 3 & Crassulaceae & Kalanchoe pinnata (Lam.) Pers. \\
\hline \multirow[t]{2}{*}{4} & Euphorbiaceae & Manihot esculenta Crantz. \\
\hline & & Ricinus communis L. \\
\hline 5 & Labiatae & Orthosiphon aristatus (Blume) Miq. \\
\hline \multirow[t]{2}{*}{6} & Liliaceae & Allium sativum L. \\
\hline & & Allium cepa L. \\
\hline 7 & Lythraceae & Lawsonia inermis L. \\
\hline 8 & Magnoliaceae & Magnolia champaca \\
\hline 9 & Malvaceae & Durio kutejensis Hassk. \& Becc. \\
\hline 10 & Moraceae & Artocarpus altilis (Parkinson) Fosberg \\
\hline \multirow[t]{2}{*}{11} & Myrtaceae & $\begin{array}{l}\text { Syzygium polyanthum (Wight) } \\
\text { Walpers. }\end{array}$ \\
\hline & & Rhodomyrtus tomentosa (Aiton) Hassk. \\
\hline 12 & Oleaceae & Jasminum sambac (L.) Sol. ex Aiton) \\
\hline \multirow[t]{2}{*}{13} & Palmae & Cocos nucifera L. \\
\hline & & Areca catechu L. \\
\hline 14 & Pandanaceae & Pandanus amaryllifolius $R o x b$. \\
\hline \multirow[t]{3}{*}{15} & Piperaceae & Piper betle L. \\
\hline & & Piper ornatum N.E.Br. \\
\hline & & $\begin{array}{l}\text { Piper nigrum } \mathrm{L} . \\
\text { Coriandrum sativum } \mathrm{L} .\end{array}$ \\
\hline \multirow[t]{3}{*}{16} & Poaceae & Imperata cylindrical (L.) Raeusch. \\
\hline & & Cymbopogon citratus (DC.) Stapf. \\
\hline & & Oryza sativa L. \\
\hline 17 & Rosaceae & Rosa sp. \\
\hline \multirow[t]{2}{*}{18} & Rubiaceae & Coffea sp. \\
\hline & & Morinda citrifolia L. \\
\hline 19 & Rutaceae & Citrus sp. \\
\hline \multirow[t]{2}{*}{20} & Solanaceae & Capsicum annuum L. \\
\hline & & Solanum lycopersicum L. \\
\hline 21 & Verbenaceae & Clerodendron calamitosum L. \\
\hline 22 & Zingiberaceae & Kaempferia galanga $\mathrm{L}$. \\
\hline
\end{tabular}

Curcuma longa L.

Zingiber officinale Roscoe.

Alpinia galanga (L.) Willd.

Kaempferia rotunda L.

Curcuma xanthorhizza Roxb.

followed by Poaceae. There are four plant species from Piperaceae and three plant species from Poaceae that is used by Tidung.

Specifically, the 20 plant species that are used as medicine is categorized in 11 plant families (Figure 2). From those 11 families, Zingiberaceae is the family that dominates plant species for medicine, then followed by Euphorbiaceae, Piperaceae, Araceae, and Rubiaceae. Figure 2 shows that there are $26 \%$ of medicinal plants are categorized as Zingiberaceae then followed by Rubiaceae, Araceae, and Euphorbiaceae which reach the percentage of $11 \%$ respectively. The least families used in Tidung life is Verbenaceae, Liliaceae, Solanaceae, Poaceae, Crassulaceae, and Labiatae the each of them only contribute $5 \%$ in medicinal plants for Tidung. From Figure 2, we also can see that the variation of plant species that are useful for medicine is high. This means that Tidung has knowledge in finding potential plants for curing diseases. This also means that Tidung do not merely depend on synthetic medicines but they prefer to use natural medicine.

As we know that the data shows that from 39 plant species found in this research, plant species from Zingiberaceae is mostly used in Tidung life. Plants from Zingiberaceae are mostly used as medicine. This shows that Zingiberaceae consists of chemical substances that are useful for medicine [8]. The usage of plants for medicine has big potential for the sustainability of human being. This is because most of those plants consist of phytochemical substances that are useful for preventing or curing diseases [9]. Some plant species that has been discovered their phytochemical substances and useful for medicine are Zingiber officinale, Curcuma domestica, Curcuma xanthorrhiza, Aloe vera, Caesalpinia sappan Linn., and Myristica fragrans [9]. In this research, plant species from Zingiberaceae that is used for medicine are Kaempferia galanga, Curcuma longa, Zingiber officinale, Curcuma xanthorrhiza, Kaempferia rotundra, and Alpinia galanga.

The most common plant from Zingiberaceae that is used as medicine is Zingiber officinale. A study on the chemical substances consist in this species shows that the fresh ginger rhizome mainly consists of sesquiterpene hydrocarbons, predominantly zingiberene, curcumene, and farnesene. Those chemical substances are categorized as volatile oil that provide specific and distinct aroma and taste of ginger [10].

Although study on ethonobaty of medicinal plants is common in Indonesia and some Asian countries like India and other countries, this study becomes something challenging in western countries such as Europe [11]. A study on ethnobotany is important in order to maintain the folk knowledge to be long lasting because mostly this knowledge is not written but transmitted orally from parents to their offspring.

In Indonesia, study on ethobotany that is related to the plant usage for medicine has been important recently. This is because Indonesia is a tropical country that has the second largest natural resources in the world after Brazil. In fact, the use of medicinal plants in Indonesia has been implemented for several years. This can be notified from some relief in Borobudur temple and medicinal plant recipes that was written from 991 to 1016 in Bali [12].

Furthermore, instead of studying ethnobotany to search for information on medicine, this study also found that some plants are useful for spices. Figure 3 shows that there are eleven plant families that has useful plant species for spices. This means that people, especially Tidung tribe have knowledge in the potency of plants for spices. This spice plants generally can give flavor for food that sometimes can increase appetite. This spice plants are also can give color for food, such as Pandanus amaryllifolius. A study on spice plants show that some spice plants can be used as herbal plants that are useful for medicine [13].

Therefore, study on the use of plant as spices is also important. Since long time ago when Indonesia was still colonialized, spice plants become an important commodity for many countries, especially the colonialists. These plants become important because of 
their role in improving foreign exchange. For Indonesia as a country that has high various plants, maintaining the sustainability of those plants is important. The richness and the variety of Indonesian food indirectly related to the variety of spice plants that are found in Indonesia. Therefore, spice plants are also important for the development of culinary and health tourisms [13].

In this research, most of spice plants are included in the family of Zingiberaceae. Figure 3 shows that there are at least four families that dominate the variety of spice plants. Those families are Poaceae, Myrtaceae, Piperaceae, and Liliaceae. Those family set up the composition of spice plants for $13 \%$ respectively. The next family that also dominates the component of spice plants is Zingiberaceae. This family has $12 \%$ of plant species number that are used as spices.

Interestingly, Durian merah (Durio kutejensis) is also used for spices. Although consider as few plant species found as spices, but this research shows that Tidung tribe use two kind of spices, which are dry and wet spices [13]. The wet spices usually consist of plants that are used without dried such as root or plant tuber. Some of the example of this wet spices are Alpinia galanga, Allium sativum, Allium cepa, Zingiber officinale, and Solanum lycopersicum. Allium cepa and Allium sativum consider as basic spices that are mostly used when people prepare food. Furthermore, one of the examples of dry spices that are used by Tidung is Piper nigrum. Among those spice plants, plants that consider as dry spices can be preserved for long time compared to the wet spices.

Unfortunately, compare to plants for medicine, plants for spices are less in their number. There are only sixteen plant species used as spices while there are 20 species used for medicine. However, this information adequately provides a big picture of the use of spice plants on Tidung tribe in North Kalimantan, Indonesia.

Instead of plants as medicine and spices, a study on ethnobotany of Tidung result in information about the plant use in traditional ceremony. It cannot be denied that most of Indonesian tribes has various traditional ceremonies that they held. When they prepare for the ceremony, most of them cannot separate from the use of plants and animal. One of traditional ceremony of Tidung that use plants is Besitan. This ceremony aims to cure a person disease. Therefore, there are some plants used in this ceremony.

The research shows that there are some plants from seven families that are used for Tidung traditional ceremonies. Among those seven families, plants from Palmae dominate the number of plants for traditional ceremonies. In this research, $24 \%$ of plants used in traditional ceremonies are coming from Palmae. Instead of Palmae, there are Rosaceae, Magnoliaceae, and Pandanaceae that dominate various kind of traditional ceremoniy plants for $13 \%$ respectively. After that, plants from Poaceae, Oleaceae, and Lythraceae consist the formation of traditional ceremony plants for $12 \%$ respectively.

Research on the use of plants for traditional ceremonies is not only conducted in Tidung tribe. Many other Indonesian tribes also held traditional ceremonies and use plants for their ceremonies. A study conducted by Hasanah, Linda, and Lovadi [4] shows that plants from
Poaceae mostly used in traditional ceremonies. Plant species from Poaceae that is mostly used in traditional ceremonies is rice (Oryza sativa). Similarly, Tidung tribe also uses Oriza sativa when they held traditional ceremony. The most plant species that is used in Tidung ceremonies are from Pandanaceae. Species from Pandanaceae that are used for the ceremonies are Cocos nucifera and Areca catechu.

Lastly, another important and interesting thing that can be found in this research is that some plants have more than one usage. Figure 5 shows that there are six families that have at least two usages. First is plant from Liliaceae that can be used for medicine and spices. The name of the species from this family is Allium sativum. The next families are Poaceae, Euphorbiaceae, and Zingiberaceae that can be used for medicine and spice. These families consist of Imperata cylindrical, Manihot esculenta, and Zingiber officinale, respectively. On the other hand, other two families have species that can be used as spices and traditional ceremonies. Those families are Palmae (Cocos nucifera) and Pandanaceae (Pandanus amaryllifolius).

\section{CONCLUSIONS}

A research on ethnobotanical study of Tidung in the North Kalimantan has been done to find out plant species and their important role for Tidung tribe. There are three groups of Tidung, Tidung Sesayap, Tidung SembakungSebuku, and Tidung Bulungan. Those three groups of Tidung are known that they have interaction with the nature in terms of using the natural resources, such as plants for their daily life. The research shows that there are 38 plant species that are used by Tidung tribe in their life. Those 38 species are used for medicine, spices, and traditional ceremonies. The 38 plant species are included in 22 families. Mostly, plants are used as medicine, then the second use is spice, and the least use is traditional ceremony. Some species have more than one usage, such as Zingiber officinale that is used as medicine and also as spices. Research on ethnobotany is important to maintain the sustainability of natural resources as well as local knowledge that is potentially lost because this knowledge is not well documented since long time ago.

\section{REFERENCES}

[1] L. Listiani and A. F.M, Kajian Folk Taxonomy dalam Penelitian Etnobotani (Studi Kasus Taksonomi Rakyat pada Beberapa Suku di Indonesia), 1st ed. Yogyakarta: Penebar Media Pustaka, 2017.

[2] J. Iskandar, Etnobouologi dan Pembangunan Berkelanjutan. Bandung: AIPI, LPPM KPK Universitas Padjajaran, 2012.

[3] L. O. R. K. Sari, "Pemanfaatan Obat Tradisional dengan Pertimbangan Manfaat dan Keamanannya," Maj. Ilmu Kefarmasian, vol. 3, no. 1, pp. 1-7, 2006.

[4] U. Hasanah, R. Linda, and I. Lovadi, "Pemanfaatan Tumbuhan pada Upacara Adat Tumpang Negeri Suku Melayu di Keraton Ismahayana Landak," Protobiont, vol. 3, no. 3, pp. 17-24, 2014.

[5] S. Basuki, Metode Penelitian. Jakarta: Penaku, 2010.

[6] S. Sugiyono, Metode Penelitian Pendidikan. Bandung: Alfabeta, 2012.

[7] L. J. Moleong, Metode Penelitian Kualitatif. Bandung: Remaja Rosdakarya, 2012.

[8] E. . Kuntorini, "Botani Ekonomi Suku Zingiberacea Sebagai Obat Tradisional oleh Masyarakat di Kotamadya Banjarbaru," Bioscientiae, vol. 2, no. 1, pp. 25-36, 2005.

[9] C. Winarti and N. Nurdjanah, "Peluang Tanaman Rempah dan Obat Sebagai Sumber Pangan Fungsional," J. Litbang Pertan., vol. 24, no. 2, pp. 47-55, 2005.

[10] S. K. Gupta and A. Sharma, "Medicinal Properties of Zingiber 
officinale Roscoe - A Review," IOSR (Journal Pharm. Biol. Sci., vol. 9, no. 5, pp. 124-129, 2014.

[11] A. Pieroni and S. Privitera, "Ethnobotany and Its Links to Medical Science and Public Health: Quo Vadis?," Zeitschrift fur Phyther., vol. 35, pp. 58-62, 2014.

[12] H. R. Dewoto, "Pengembangan Obat Tradisional Indonesia Menjadi Fitofarmaka," Maj. Kedokt. Indones., vol. 57, no. 7, pp. 205-211, 2007.

[13] L. Hakim, J. Batoro, and K. Suketi, "Etnobotani RempahRempah di Dusun Kopen Dukuh, Kabupaten Banyuwangi," J$P A L$, vol. 6, no. 2, pp. 133-142, 2015. 